\title{
The Role of Light and an Aggregation Stimulating Factor During Aggregation of Polysphondylium violaceum
}

\author{
By LAURA A. TETA, $\dagger$ CATHERINE F. ELLSAESSER AND \\ MICHAEL H. HANNA* \\ Biology Department, Rensselaer Polytechnic Institute, Troy, New York 12181, U.S.A.
}

(Received 21 January 1982; revised 7 June 1982)

\begin{abstract}
Light has been shown to affect aggregation and founder cell development in the cellular slime mould Polysphondylium violaceum. An aggregation-stimulating factor, D factor, also affects aggregation of $P$. violaceum wild-type and aggregation-defective mutants in the complementation group agg $A$. Both light and $D$ factor cause premature aggregation of amoebae and increase the number of aggregate centres formed. In addition, $D$ factor is able to stimulate aggregation of wild-type amoebae at densities where aggregation would not normally occur. Several experiments show that amoebae are more sensitive to $\mathrm{D}$ factor in the presence of light, with optimum aggregation occurring in the presence of both light and D factor. Development of founder cells has been observed in the aggA mutants in the absence of D factor. However, these founder cells are inactive and do not produce aggregates until $\mathbf{D}$ factor is added. This class of inactive founder cells can be detected in wild-type amoebae. Production of $\mathbf{D}$ factor is also dependent on light with a 20- to 60-fold decrease in production over that occurring in darkness. A complex relationship between $D$ factor, light and founder cell differentiation is established by this study.
\end{abstract}

\section{INTRODUCTION}

Light has been shown to have a number of different effects on differentiation and movement in the cellular slime moulds. Individual amoebae (Hader \& Poff, 1979 a) and slugs (Bonner et al., 1950; Francis, 1964; Poff et al., 1973) of Dictyostelium discoideum exhibit a phototactic response to light. The phototaxis shown in slugs has a different action spectrum from that for individual amoebae (Hader \& Poff, $1979 a$ ). Aggregate formation by $D$. discoideum amoebae is also affected by light. Konijn \& Raper (1966) have shown that continuous exposure to light causes a greater number of aggregate centres to be formed than would be formed in darkness, though the cells start to aggregate at the same time in either condition. However, preincubation in darkness for several hours followed by incubation in light causes premature aggregation of the amoebae (Konijn \& Raper, 1965). Finally, Hader \& Poff (1979b). showed that at high light intensities aggregation of $D$. discoideum is inhibited.

Aggregation in a variety of other cellular slime mould species is affected by light. Dictyostelium mucoroides, Dictyostelium purpureum, Dictyostelium lacteum, Polysphondylium violaceum and Polysphondylium pallidum all aggregate earlier and produce a greater number of aggregate centres if exposed to continuous illumination (Shaffer, 1961; Kahn, 1964; Konijn \& Raper, 1965; Perekalin, 1977). In P. violaceum the number of 'founder' cells (first cell to establish an aggregate) increases within one half to one hour after illumination (Shaffer, 1961) suggesting that the increase in the number of aggregate centres is due to an increase in the number of founder cells. Polysphondylium violaceum also produces an aggregation stimulating factor,

$\dagger$ Present address: Department of Biology, University of Houston, Houston, Texas 7004, U.S.A. 
$\mathrm{D}$ factor, that will cause a specific class of aggregation-defective mutants, agg $A$, to develop normally (Hanna \& Cox, 1978). D factor is excreted by wild-type amoebae prior to aggregation with little or no production of $D$ factor occurring during vegetative growth. Since both light and $D$ factor seem to exert their influence on aggregate formation, we began to explore the relationship between them. In this paper we demonstrate that both light and D factor affect aggregation of $P$. violaceum in a similar manner. We also describe several features of founder cells and suggest that the $a g g A$ mutants require $\mathrm{D}$ factor in order to make active founder cells.

\section{METHODS}

Growth conditions. Polysphondylium violaceum no. 1 and tsg-119 cyc-1 aggA586 (referred to as aggA586 in the text), an aggregation-defective mutant of $P$. violaceum (Warren et al., 1975, 1976), were grown in association with Escherichia coli $\mathrm{B} / \mathrm{r}$ on GYP agar $\left(\mathrm{g}^{-1}\right)$ : glucose, 1; peptone, 2; yeast extract, $0.25 ; \mathrm{KH}_{2} \mathrm{PO}_{4}, \mathbf{4} \cdot 2$; $\mathrm{Na}_{2} \mathrm{HPO}_{4} .7 \mathrm{H}_{2} \mathrm{O}, 5 \cdot 1$; agar, 20 (Weber, 1970 ) or $2 \%$ agar containing $1 \%$ glucose and $1 \times$ VB salts (Vogel \& Bonner, 1956). Growth plates were incubated at $22{ }^{\circ} \mathrm{C}$ in darkness unless indicated otherwise.

Starvation and development conditions. In all experiments with $P$. violaceum, amoebae were harvested while still in vegetative growth. Plates with aggA586 were harvested either while growth was still vegetative or after the plates had begun to clear (indicative of the removal of most of the bacteria by the mutant amoebae). In all cases the amoebae were scraped from the surface of the plates after flooding with $1 \% \mathrm{BSS}\left(\mathrm{mg} \mathrm{l}^{-1}\right) ; \mathrm{NaCl}, 6 ; \mathrm{KCl}, 7 \cdot 5$; $\mathrm{CaCl}_{2}, 3$ (Bonner, 1947); suspensions were centrifuged at $700 \mathrm{~g}$ for $8 \mathrm{~min}$. The pellet was washed twice with $1 \%$ BSS and resuspended in $1 \%$ BSS. Development of the amoebae was followed on LPS non-nutrient agar (Newell et al., 1969) in the presence or absence of D factor (Hanna \& Cox, 1978). Noble agar (Difco) was used in all of the non-nutrient plates $\left(15 \mathrm{~g} \mathrm{l}^{-1}\right)$ and the plates were made up $24 \mathrm{~h}$ in advance to allow sufficient time for them to dry. In experiments where $D$ factor was used, an appropriate dilution of $D$ factor was mixed with an equivalent volume of LPS agar and poured into Petri dishes. Amoebae were dispensed onto the LPS agar at the densities indicated in the text either as $0.5 \mu$ drops ('tiny drops') or $25 \mu$ drops ('large drops'). Generally, 16 tiny drops or 6 large drops were evenly spaced on each $15 \times 60 \mathrm{~mm}$ dish containing $6 \mathrm{ml}$ LPS agar (or LPS agar plus D factor). Plates were incubated at $22{ }^{\circ} \mathrm{C}$ either in darkness or in the light in a Precision Illuminated Low-Temperature Incubator $\left(16 \mathrm{ft}^{3}\right.$; $0.448 \mathrm{~m}^{3}$ ) with two $40 \mathrm{~W}$ fluorescent lamps mounted in the door. The plates were $25 \mathrm{~cm}$ from the lamps (approximately $1400 \mathrm{~lx}$, measured using a Gossen Luna-Pro light meter). The amoebae were monitored frequently for the first 5 to $8 \mathrm{~h}$ of development and again after $24 \mathrm{~h}$ when development to fruiting bodies was complete.

$D$ factor production and assay. D factor was produced from $P$. violaceum and assayed with agg $A 586$ as described previously (Hanna \& Cox, 1978). Briefly, D factor is prepared by incubation of $10^{8}$ prewashed, vegetative amoebae on a dialysis membrane held taut between two interlocking polycarbonate rings in a sterile chamber filled with LPS buffer up to the surface of the dialysis membrane $(25 \mathrm{ml}$ capacity). After development for $48 \mathrm{~h}$ the dialysate was collected. This crude dialysate contained $D$ factor that can stimulate aggregation even after a 1/1000 dilution. In all of the tiny and large drop experiments, the crude $D$ factor had been further purified and concentrated by butanol extraction and partitioning in a chloroform/methanol/water $(8: 4: 3$, by vol.) system (Folch et al., 1957). D factor was recovered in the chloroform phase with very little loss of activity (E. A. Ruff \& M. H. Hanna, unpublished results). The organic solvents were removed by rotary evaporation and the $D$ factor residue resuspended in LPS buffer prior to being added to the LPS agar. The resuspended D factor was often concentrated up to 60 -fold by these procedures.

Conditions for monitoring founder cells. Vegetative wild-type $P$. violaceum or aggA586 mutants were harvested and resuspended in liquid culture as previously described (Gardner \& Hanna, 1982). After 2 to $3 \mathrm{~h}$ incubation, amoebae were removed from liquid culture, vortexed to break any cell contacts and $4 \mu \mathrm{l}$ was spread on coverslips. The coverslips were inverted over depression slides and the edges sealed with stopcock grease. These slides were observed and photographed using an Olympus BH phase contrast microscope fitted with a $35 \mathrm{~mm}$ camera. These developmental conditions are similar to those described by Beug et al. (1973) for monitoring aggregation competence.

\section{RESULTS}

\section{The effect of light on aggregation of $P$. violaceum no. 1}

The effect of light on aggregation of $P$. violaceum no. 1 is illustrated in Fig. 1. A comparison of Fig. $1(a)$ with $1(b)$ indicates that in the light more aggregate centres were formed, there was very little streaming, and the aggregates were more advanced than those in darkness. In addition, aggregation was apparent in light 60 to $90 \mathrm{~min}$ earlier than it was in darkness (data not shown). Our strain of $\boldsymbol{P}$. violaceum behaved similarly to those previously described (Shaffer, 1961; Konijn \& Raper, 1965; Perekalin, 1977). 

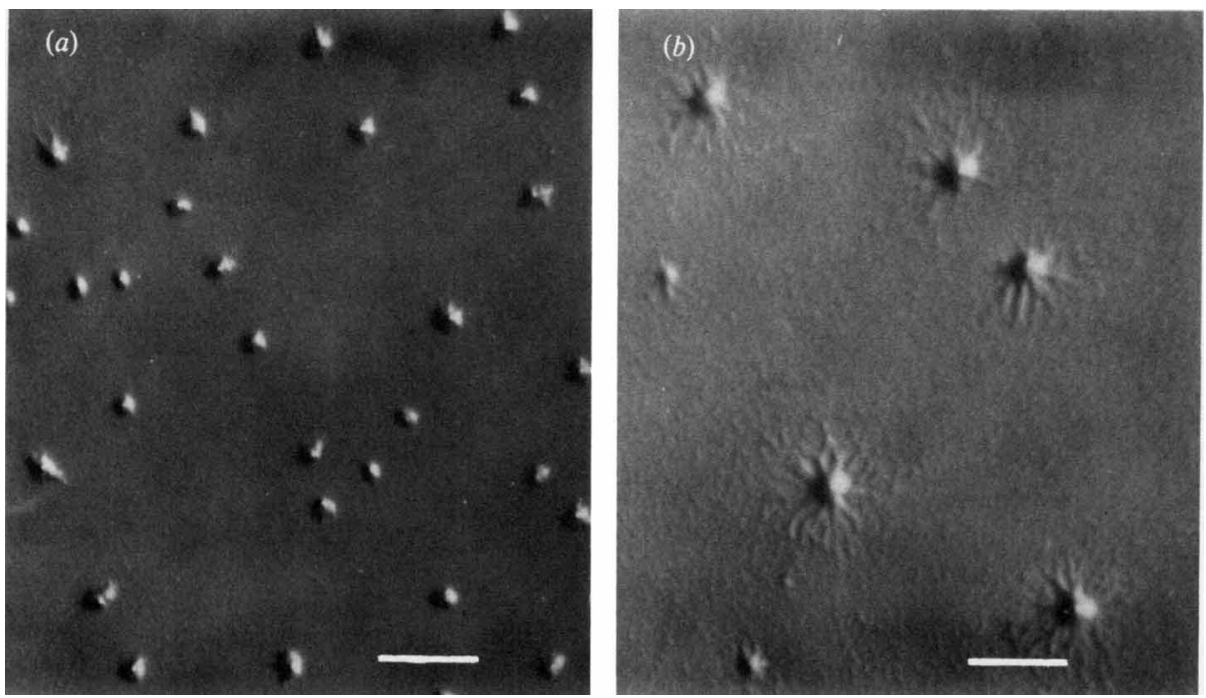

Fig. 1. Effect of light on aggregation of $P$. violaceum no. 1. Vegetative $P$. violaceum were harvested as described in Methods and resuspended at $5 \times 10^{6}$ cells $\mathrm{ml}^{-1}$. Drops $(25 \mu \mathrm{l})$ were put on LPS nonnutrient agar and incubated at $22^{\circ} \mathrm{C}$ in light or darkness. (a) Aggregation in light $3.5 \mathrm{~h}$ after the cells were put on the agar. (b) Aggregation in darkness after $3.5 \mathrm{~h}$. The photographs were taken with a Wild M5 stereomicroscope with a Polaroid camera attachment. The bar marker represents $0.5 \mathrm{~mm}$.

To monitor founder cell differentiation we have observed over 15000 amoebae and hundreds of aggregates during the course of several experiments. Aggregates are always started by amoebae that are round for various times prior to attracting a few neighbouring amoebae (Fig. $2 a, b$ and $c$ ). Larger aggregates form after several minutes (Fig. $2 d$ ) and in these directed movement of elongated amoebae can be seen. As amoebae enter the aggregate they round up making it difficult to distinguish them from the original founder cell. Normally 2 to $3 \%$ of all amoebae are round, but only some of these attract amoebae and establish an aggregate. Two other classes of round cells can therefore be distinguished from active founder cells. First, there are round cells that never seem to attract amoebae. Second, there are round cells that attract a few amoebae, hold them for a few minutes and then dissociate. These we call transient founder cells. The three classes of round cells can only be distinguished after long periods of microscopic observation.

\section{Light and $D$ factor both cause premature aggregation}

The first sign of aggregation can be accurately determined by plating amoebae as uniform tiny drops $(0.5 \mu \mathrm{l})$ on buffered non-nutrient agar and monitoring development in each drop at frequent intervals (Konijn \& Raper, 1961). The experiments illustrated in Fig. 3 show that both $\mathrm{D}$ factor and light cause premature aggregation of wild-type amoebae. The time differences shown between aggregation in the light or dark could be increased by decreasing the density of amoebae in the tiny drops (data not shown). Although $D$ factor was more effective than light at stimulating aggregation, optimum aggregation occurred in the presence of both agents. The rate of aggregation was dependent on the concentration of $\mathrm{D}$ factor added to the agar.

The agg A586 mutants require D factor in order to aggregate (Hanna \& Cox, 1978). In experiments identical to those with wild-type cells, aggA586 mutants aggregated slightly faster in light with $D$ factor than in darkness with $D$ factor (Fig. 4). However, when incubated in light, the agg $A 586$ mutants showed a greater sensitivity to $\mathrm{D}$ factor, since dilutions that would not promote aggregation in darkness (1/80 and 1/160) were effective in light. If late-exponential phase amoebae were used and the cell density in the drop increased over that used in Fig. 3, the aggA586 mutant began to aggregate even earlier and responded to lower concentrations of $\mathrm{D}$ 

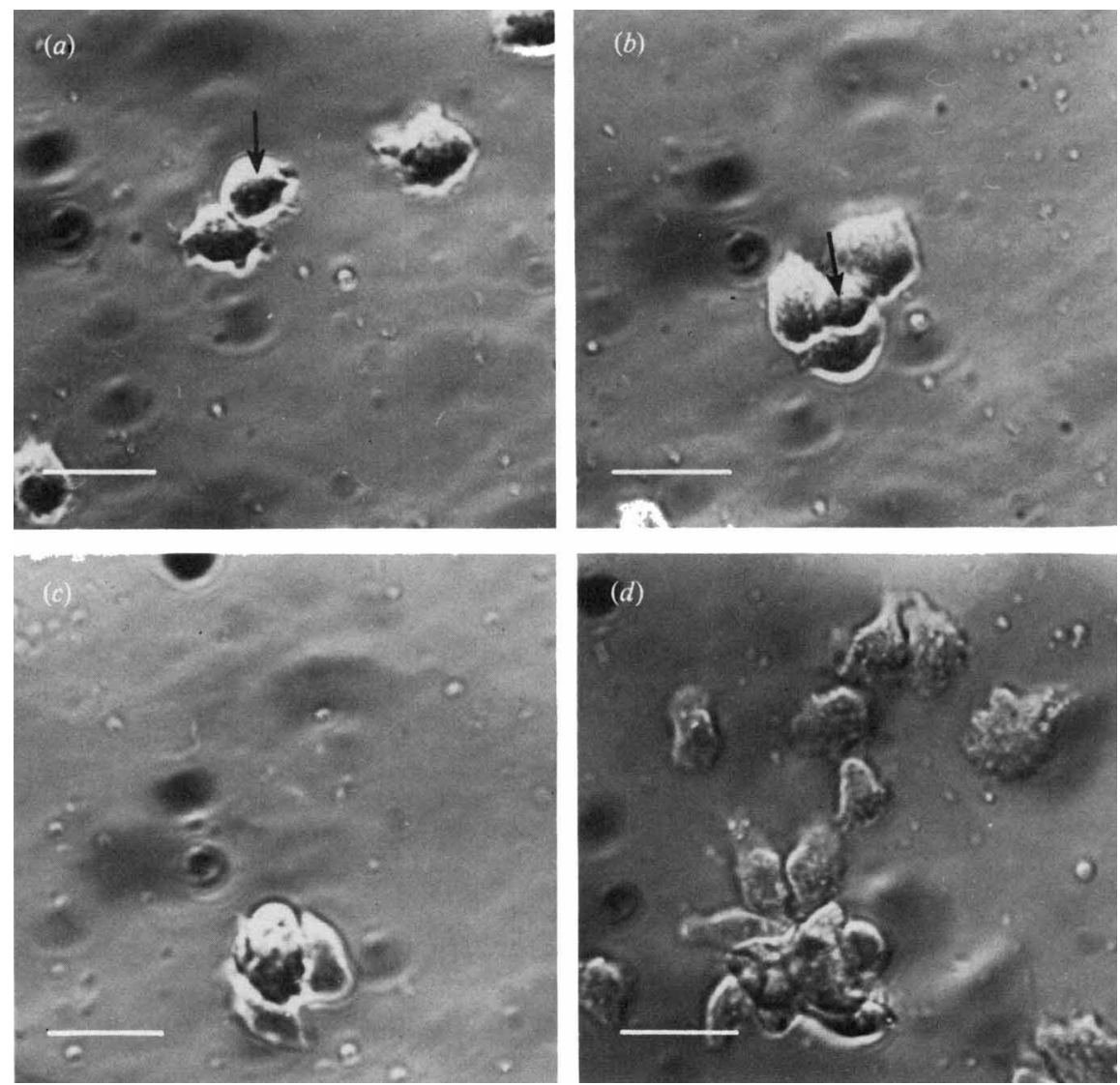

Fig. 2. Founder cell differentiation in $P$. violaceum no. 1. Vegetative $P$. violaceum were harvested as described in Methods and incubated in liquid culture at $1 \times 10^{7}$ cells $\mathrm{ml}^{-1}$. After $2 \mathrm{~h}$ incubation, samples were vortexed, diluted to $2.5 \times 10^{6}$ cells ml $^{-1}$ and $4 \mu$ were spread on a coverslip and observed for founder cells as described in Methods. The slides were incubated in the light. (a) $t_{0}$, First picture of active founder cell with one amoeba attached; (b) $1 \mathrm{~min}$ later; $(c) 2 \mathrm{~min}$ later; $(d) 5$ min later. The founder cell is arrowed. The bar marker represents $10 \mu \mathrm{m}$.

factor both in light and darkness (data not shown). We have presented the data, using less than optimal conditions for the mutant, to allow direct comparison of the data with the wild-type response. The trend was the same as that shown in Fig. 4 regardless of the density of the mutant cells.

\section{$D$ factor stimulates aggregation at low cell densities}

At a cell density of $1.0 \times 10^{6}$ cells ml ${ }^{-1}$, very few tiny $(0.5 \mu \mathrm{l})$ drops (approximately 500 amoebae per drop) showed any signs of aggregation or further development whether incubated in light or darkness (Table 1). However, if $\mathrm{D}$ factor was provided, significant development occurred even at the lowest cell densities used. At lower D factor concentrations than those in Table 1, the response of the amoebae was somewhat less.

\section{Stimulation of aggregate centre formation by light and $D$ factor}

Light has been reported to cause an increase in the number of aggregate centres formed with P. violaceum (Shaffer, 1961; Konijn \& Raper, 1965; Perekalin, 1977) and this is confirmed in Fig. 1 and Table 2, a 3-fold increase being observed. The addition of $D$ factor stimulated aggregate formation both in light (1.5-fold increase) and in darkness (2-fold increase). We were 


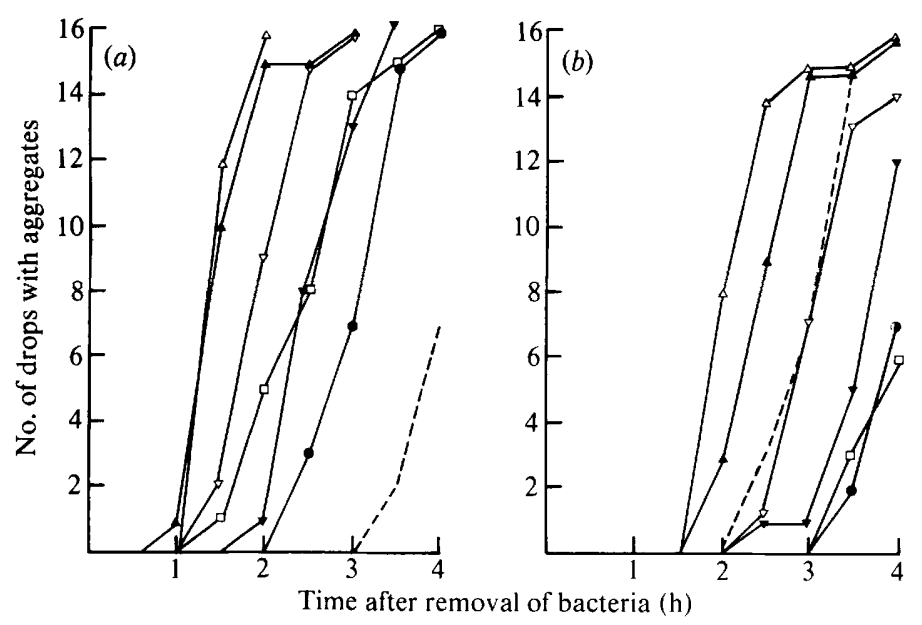

Fig. 3. Effect of light and $D$ factor on the time of cell aggregation of $P$. violaceum. Vegetative $P$. violaceum were harvested as described in Methods and resuspended at $2.5 \times 10^{7} \mathrm{cells} \mathrm{ml}^{-1}$. Sixteen drops $(0.5 \mu \mathrm{l})$ were spaced at regular intervals on $60 \mathrm{~mm}$ diameter plastic Petri dishes containing LPS non-nutrient agar without $\mathrm{D}$ factor or containing the indicated dilutions of $\mathrm{D}$ factor $(\mathrm{D}$ factor active to a final dilution of $1 / 16000)$. Dishes were incubated at $22^{\circ} \mathrm{C}$ in the light $(a)$, or in darkness $(b)$ and observed at $30 \mathrm{~min}$ intervals. A drop is scored as positive at the first sign of aggregation in that drop. $\bigcirc$, No $D$ factor; $\triangle, 1 / 10$ dilution; $\triangle, 1 / 20$ dilution; $\nabla, 1 / 40$ dilution; $\nabla, 1 / 80$ dilution; $\square, 1 / 160$ dilution. The broken lines represent: in $(a)$ the dark-incubated control without $\mathrm{D}$ factor, and in $(b)$ the lighi incubated control without D factor.

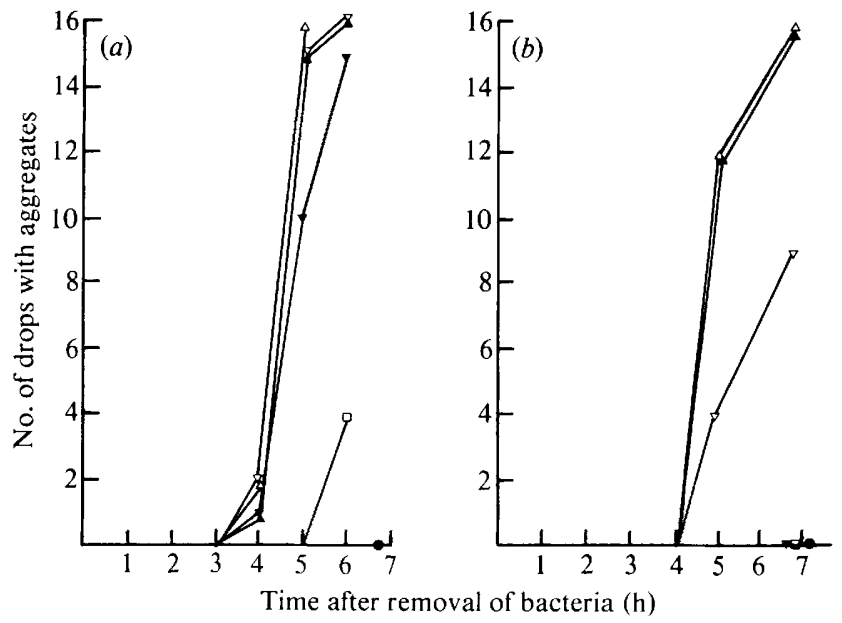

Fig. 4. Effect of light and D factor on the time of cell aggregation of aggA586 mutants. Vegetative tsg-119 cyc-1 agg A586 were harvested as described in Methods and resuspended at $2.5 \times 10^{7} \mathrm{cells} \mathrm{ml}^{-1}$. The mutant amoebae were treated exactly as the wild-type in Fig. 2 except that the $D$ factor was active to approximately $1 / 8200$. Dishes were incubated at $22^{\circ} \mathrm{C}$ in the light $(a)$, or in darkness $(b)$ and observed at $30 \mathrm{~min}$ intervals.. No $\mathbf{D}$ factor; $\triangle, 1 / 10$ dilution; $\Delta, 1 / 20$ dilution; $\nabla, 1 / 40$ dilution; $\nabla, 1 / 80$ dilution; $\square, 1 / 160$ dilution. A mutant control plate without $D$ factor was also incubated in the light and in darkness.

not able to equal the light-dependent stimulation of aggregate centres with cells incubated in darkness in the presence of $\mathrm{D}$ factor even when higher concentrations of $\mathrm{D}$ factor were used.

$\mathrm{D}$ factor also stimulated centre formation in the mutant agg A586 (Table 3) and with high concentrations a significant number of aggregates developed into fruiting bodies. The agg A586 mutant again was most sensitive to $D$ factor in the light, with concentrations of $D$ factor as low as $1 / 160$ promoting significant aggregation of the mutant. 
Table 1. Effect of light and $D$ factor on aggregation of $P$. violaceum at low cell densities

Polysphondylium violaceum were harvested while still in exponential growth and the bacteria removed as described in Methods. The amoebae were resuspended at the indicated densities and sixteen drops $(0.5 \mu \mathrm{l})$ were spotted at regular intervals on non-nutrient agar plates with or without $\mathrm{D}$ factor. Duplicate sets of plates were then incubated either in light or darkness at $22^{\circ} \mathrm{C}$. After $24 \mathrm{~h}$, the drops were individually scored to determine whether the amoebae had developed. By this time drops scored as positive had fruiting bodies and drops scored negative had no development. The data were with D factor diluted $1 / 10$ and active at 1/8200 final dilution.

$\begin{array}{lcccc}\overbrace{\text { Cells ml }}^{-1} & \overbrace{\text { +D factor }}^{\text {Light }} & \text { No. of drops showing development after } 24 \mathrm{~h} & \overbrace{\text { +D factor }}^{\text {Dark }} \\ 2.5 \times 10^{7} & 16 & 16 & 16 & -D \text { factor } \\ 1.0 \times 10^{7} & 16 & 15 & 16 & 16 \\ 5.0 \times 10^{6} & 16 & 15 & 16 & 16 \\ 2.5 \times 10^{6} & 16 & 4 & 16 & 9 \\ 1.0 \times 10^{6} & 15 & 0 & 13 & 2\end{array}$

Table 2. Effect of light and $D$ factor on the number of aggregation centres with $P$. violaceum

\begin{abstract}
Exponentially growing $P$. violaceum were harvested as described in Methods and resuspended at $5 \times$ $10^{6}$ amoebae $\mathrm{ml}^{-1}$. Six $25 \mu \mathrm{l}$ drops were spotted on non-nutrient agar with or without $\mathrm{D}$ factor. One set of plates was incubated in light and another set in darkness, both at $22^{\circ} \mathrm{C}$. The number of aggregates in each drop was counted until aggregation was over (generally 5 to $7 \mathrm{~h}$ ) and a final reading taken after $24 \mathrm{~h}$. By $24 \mathrm{~h}$ the amoebae had developed into fruiting bodies. The number of fruiting bodies is roughly equivalent to the number of aggregates, generally with at most a $10 \%$ change from the 5 to $7 \mathrm{~h}$ readings. We have used these $24 \mathrm{~h}$ readings in order to pick up aggregates that occur at later times. The values are the average of six drops on each plate \pm S.D. Statistical evaluation of this data (Students $t$ test, $95 \%$ confidence) showed that the number of aggregates formed in the presence of $\mathrm{D}$ factor in darkness (or in light) was significantly different from the number formed in the absence of $D$ factor in darkness (or in light). $\mathrm{D}$ factor used in this experiment was active to a final dilution of $1 / 64000$.
\end{abstract}

$\begin{array}{cccc}\begin{array}{c}\text { Assay } \\ \text { conditions }\end{array} & \begin{array}{c}\text { D factor } \\ \text { concentration } \\ \text { (dilution) }\end{array} & \begin{array}{c}\text { Mean no. } \\ \text { of aggregates } \\ \text { per 25 } \mu \text { l drop }\end{array} & \text { Ratio* } \\ \text { Light } & 0 & 87.8 \pm 6 \cdot 8 & \\ \text { Light } & 1 / 80 & 139.5 \pm 10 \cdot 1 & 1 \cdot 58 \\ \text { Light } & 1 / 160 & 136 \pm 9 \cdot 2 & 1.54 \\ \text { Light } & 1 / 320 & 111 \cdot 3 \pm 14 \cdot 3 & 1 \cdot 27 \\ \text { Dark } & 0 & 32 \cdot 3 \pm 4 \cdot 2 & \\ \text { Dark } & 1 / 80 & 61 \pm 2 \cdot 9 & 1.89 \\ \text { Dark } & 1 / 160 & 53 \pm 6.4 & 1.64 \\ \text { Dark } & 1 / 320 & 44.3 \pm 4.3 & 1.37\end{array}$

* Ratio of the number of aggregates per drop in the presence of $D$ factor to the number of aggregates per drop in the absence of $\mathrm{D}$ factor (amoebae assayed in light are compared only with others in light; amoebae assayed in darkness are similarly compared).

\title{
Founder cells in the aggA mutants
}

Approximately 2 to $2.5 \%$ of the agg $A 586$ amoebae after $3 \mathrm{~h}$ of development are round. None of these round cells, after observation of approximately 350 round cells out of a total of 15000 cells, has ever shown properties of an active founder cell; all are either inactive or transient founder cells (Fig. $5 a$ ). In the presence of $\mathrm{D}$ factor, active founder cells are observed and aggregates are formed (Fig. $5 b-d$ ). There are two possible explanations for this observation. First, founder cells are inactive except in the presence of D factor. Second, founder cells are a discrete class of round cells and are specifically induced by $D$ factor. At the moment we cannot distinguish between these possibilities. 
Table 3. Effect of light and D factor on the number of aggregation centres with aggA586 mutants

Vegetative $t s g-119 c y c-1$ agg $A 586$ were harvested and treated exactly as described for wild-type $P$. violaceum in Table 2 . The $\mathrm{D}$ factor used in this experiment was active to a final dilution of $1 / 8000$.

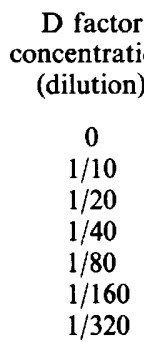

Mean no. of aggregates per $25 \mu l$ drop

$\overbrace{\text { Light Dark }}$

$\begin{array}{rc}0.7 \pm 0.94 & 0 \\ 60 \cdot 2 \pm 8 \cdot 1 & 17.2 \pm 3.3 \\ 46 \cdot 3 \pm 8 \cdot 0 & 15.3 \pm 3.4 \\ 29.7 \pm 4.2 & 3.3 \pm 1.5 \\ 21.8 \pm 3.3 & 0.33 \pm 0.74 \\ 12 \pm 4.1 & \text { NT } \\ 1.83 \pm 1 \cdot 2 & \text { NT }\end{array}$

NT, Not tested.
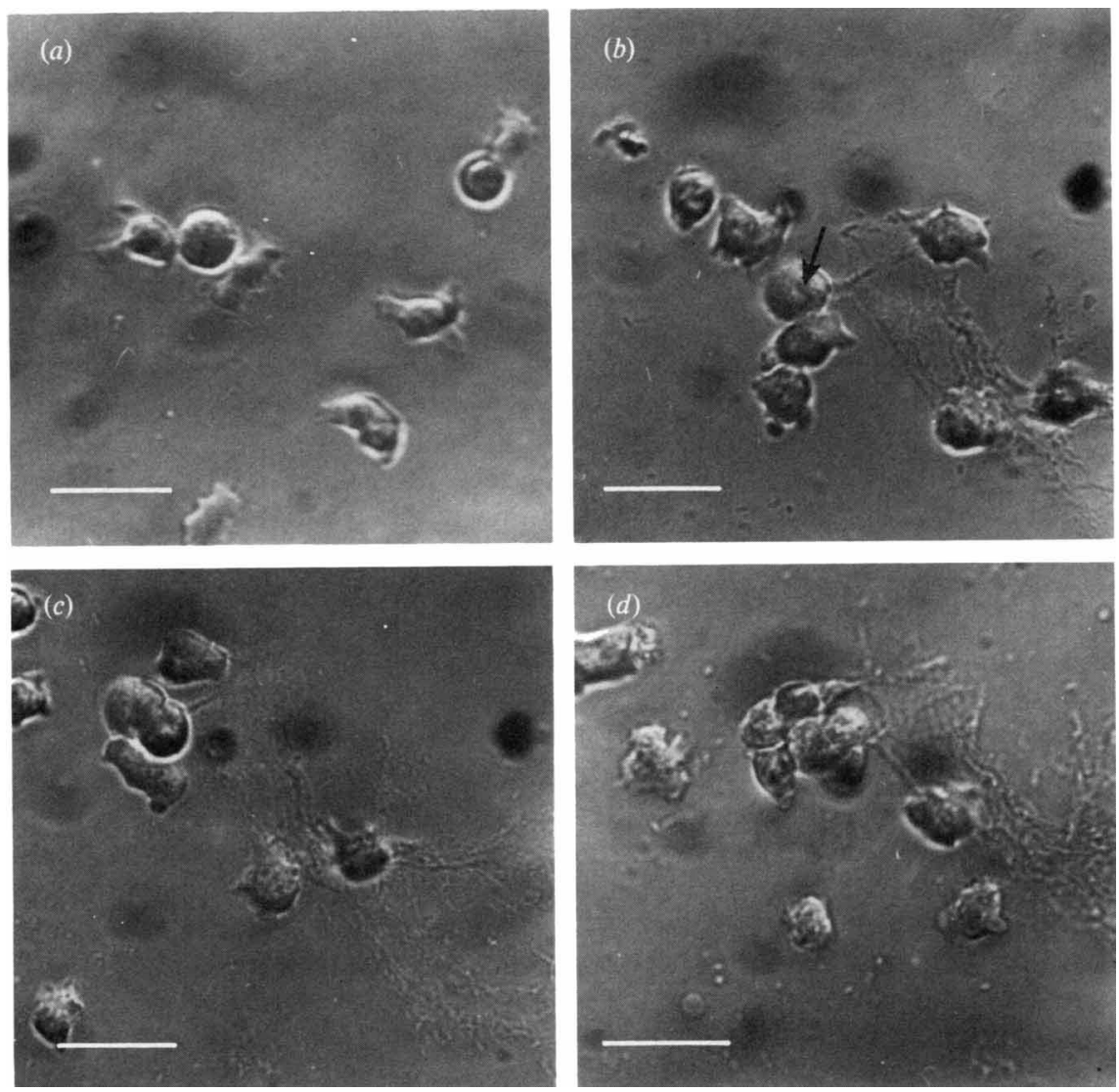

Fig. 5. Founder cell differentiation in aggA mutants. Vegetative agg A586 were treated as described in Fig. 2 for observation of founder cells, except the amoebae were preincubated in liquid culture for $3 \mathrm{~h}$ and the slides were incubated in darkness. (a) Transiently active founder cells in the absence of D factor; $(b)$ active founder cell in the presence of concentrated $D$ factor ( $1 / 25$ dilution, active to $1 / 25000$ final dilution); $(c)$ as $(b), 1 \mathrm{~min}$ later; $(d)$ as $(b), 3 \mathrm{~min}$ later. The founder cell is arrowed. The bar marker represents $10 \mu \mathrm{m}$. 
Table 4. Effect of light on production of $D$ factor by $P$. violaceum and assay of $D$ factor with agg A586 mutants

Polysphondylium violaceum was grown either in light or darkness at $22{ }^{\circ} \mathrm{C}$, harvested while still in exponential growth, and used to produce $\mathrm{D}$ factor as described in Methods. The cells grown in darkness were split into two batches and incubated either in darkness or light for production of D factor. Those cells grown in light were similarly treated for $D$ factor production. After $48 \mathrm{~h}$ incubation, all $\mathrm{D}$ factor was harvested and tested for activity with $t s g-119 \mathrm{cyc}-1 \mathrm{agg} \mathrm{A586}$ as described in Methods. Duplicate sets of D factor plates were made for each sample with one set incubated in light and the other in darkness. The $\mathrm{D}$ factor activity endpoint was determined after $48 \mathrm{~h}$ incubation.

\begin{tabular}{|c|c|c|c|c|c|}
\hline \multirow{2}{*}{$\begin{array}{l}\text { Growth } \\
\text { conditions }\end{array}$} & \multirow{2}{*}{$\begin{array}{l}\mathrm{D} \text { factor } \\
\text { production } \\
\text { conditions }\end{array}$} & \multicolumn{2}{|c|}{$\begin{array}{l}\text { D factor activity } \\
\text { endpoint* }\end{array}$} & \multirow{2}{*}{$\begin{array}{l}\text { D factor } \\
\text { production } \dagger \\
\text { (Ratio D } / \mathrm{L})\end{array}$} & \multirow{2}{*}{$\begin{array}{c}\text { Increased } \\
\text { sensitivity } \\
\text { of mutant } \\
\text { in assay } \ddagger \\
\text { (Ratio L/D) }\end{array}$} \\
\hline & & Dark & Light & & \\
\hline Dark & Dark & $1 / 1024$ & $1 / 131000$ & & $>125$ \\
\hline Dark & Light & $1 / 16$ & $1 / 131000$ & 64 & $>8100$ \\
\hline Light & Dark & $1 / 1024$ & $1 / 131000$ & & $>125$ \\
\hline Light & Light & $1 / 64$ & $1 / 131000$ & 16 & $>2000$ \\
\hline
\end{tabular}

* The last two-fold serial dilution having any development when $t s g-119 \mathrm{cyc}-1$ aggA586 was spread on the plate and allowed to develop for $48 \mathrm{~h}$.

$\dagger \mathrm{D}$ factor production was determined by assaying twofold serial dilutions of the factor with $t s g-119 \mathrm{cyc}-1$ agg $A 586$ incubated in darkness only (data in column 3 ).

$\ddagger$ Compares response of mutant tsg-119 cyc-1 agg A586 incubated either in light or darkness with the same batch of $\mathrm{D}$ factor (compare data in column 4 with those in column 3 ).

\section{Production of $D$ factor is reduced in light}

In all previous experiments $D$ factor had been produced from wild-type $P$. violaceum incubated in darkness (Hanna \& Cox, 1978). The top two lines in Table 4 show that the production of $\mathrm{D}$ factor by dark-incubated wild-type amoebae was approximately 60 -fold greater than in the light, when assayed under standard conditions with the agg $A 586$ mutant. This decreased activity is confirmed in Fig. $6(a, b)$ where the agg $A 586$ mutant response to a $1 / 16$ dilution of $\mathrm{D}$ factor made in darkness (Fig. $6 a$ ), is significantly greater than that to a $1 / 16$ dilution of $\mathrm{D}$ factor made in light. The reduced $\mathrm{D}$ factor production in the light was not due to photochemical degradation because control experiments showed that dark-produced D factor could be incubated in the light for $48 \mathrm{~h}$ without loss of activity (data not shown). Growth of the amoebae in light did not seem greatly to affect subsequent $D$ factor production either in light or darkness (Table 4, lines 3 and 4). In four other experiments similar to that shown in Table 4, the increased production of $\mathrm{D}$ factor in the dark was between 16- and 64-fold, regardless of the light conditions used during growth of the amoebae.

Regardless of the conditions for production of $\mathrm{D}$ factor, when assayed with the agg $A 586$ mutant in light, all $D$ factor preparations were active at least to a dilution of $1 / 131000$. Darkproduced $\mathrm{D}$ factor always promoted a significantly greater response than did light-produced D factor at comparable dilutions (compare Fig. $6 c, e$ to $d, f$ ). At extremely high dilutions of light- or dark-produced $D$ factor only one or two tiny fruiting bodies were detected after incubation of agg A586 in light (Fig. 6e,f). It was not possible to determine whether these fruiting bodies developed from normal aggregates, since the size of the resulting fruiting body was so small that aggregation could not be observed over a background of unresponsive amoebae.

\section{DISCUSSION}

In the experiments described in this paper, we have shown that both light and an aggregation stimulating factor, D factor, affect aggregation in $P$. violaceum in a similar manner. In Polysphondylium species the first cell to begin autonomous excretion of the chemo-attractant and establish an aggregate is called a founder cell (Shaffer, 1961) and these appear as small round amoebae which, early during aggregation, attract elongated amoebae. Light causes an increase in the number of founder cells produced by $P$. violaceum (Shaffer, 1961) and so increases the 

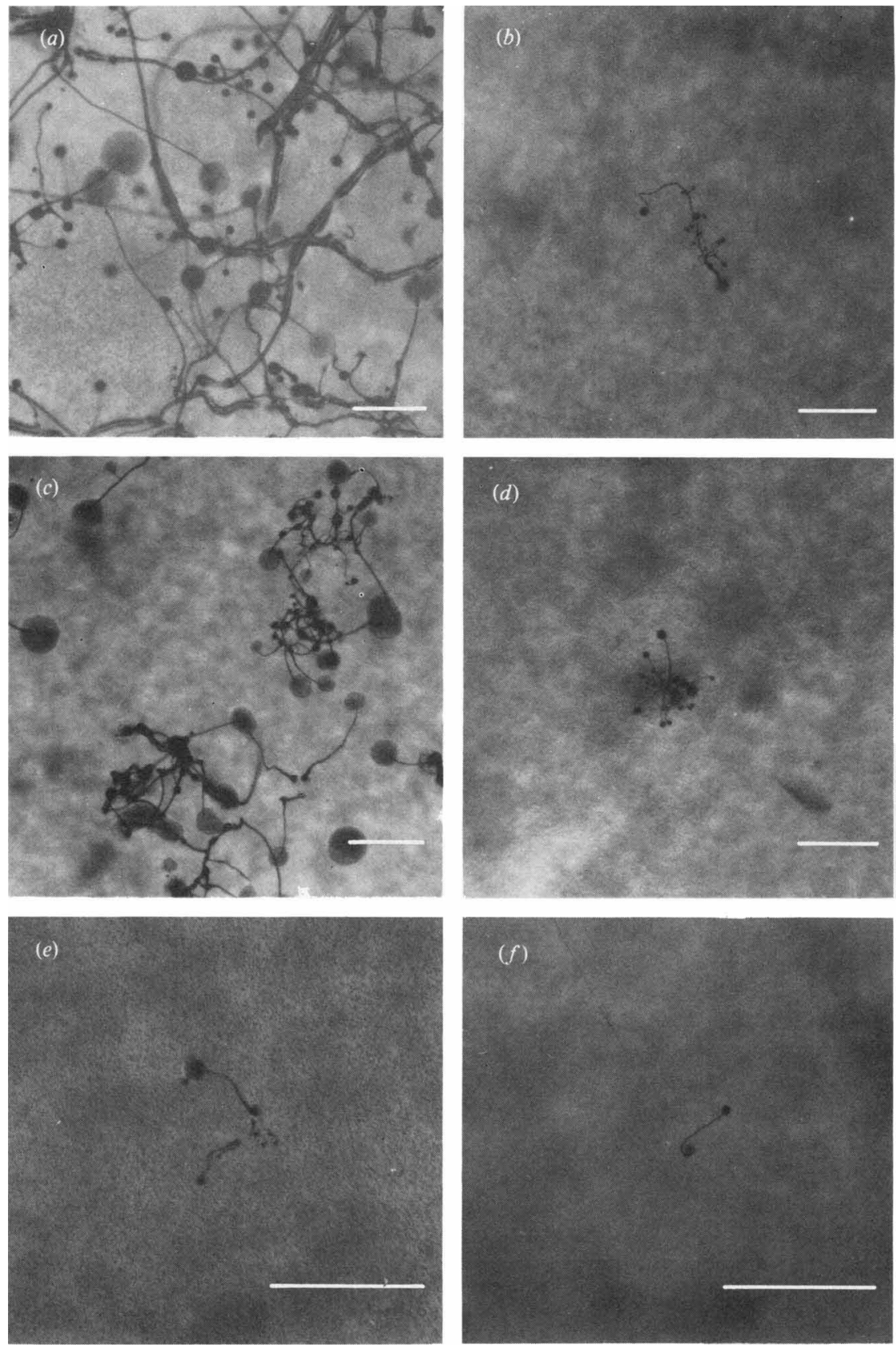

Fig. 6. Development of $a g g A 586$ mutants with $\mathrm{D}$ factor produced under different conditions and assayed in either light or darkness. Partially cleared $t s g-119 \mathrm{cyc}-1$ agg A586 were harvested as described in Methods and resuspended at $2 \times 10^{8}$ cells $\mathrm{ml}^{-1} ; 0 \cdot 1 \mathrm{ml}$ was spread on LPS non-nutrient agar containing the indicated dilution of $\mathrm{D}$ factor. The $\mathrm{D}$ factor was from wild-type cells grown in darkness with $\mathrm{D}$ factor produced during incubation in darkness $(a, c, e)$ or light $(b, d, f)$, and corresponds to the data in lines 1 and 2 of Table 4. (a) 1/16 dilution of $D$ factor produced in darkness, assayed in darkness; (b) 1/16 dilution of D factor produced in light, assayed in darkness; (c) 1/128 dilution of D factor produced in darkness, assayed in light; $(d) 1 / 128$ dilution of $\mathrm{D}$ factor produced in light, assayed in light; (e) 1/131000 dilution of $\mathrm{D}$ factor produced in darkness, assayed in light; $(f)$ 1/131000 dilution of $\mathrm{D}$ factor produced in light, assayed in light. The photographs were made with a Wild M5 stereomicroscope with a Polaroid camera attachment after the plates had been incubated at $22^{\circ} \mathrm{C}$ for $48 \mathrm{~h}$. The bar markers represent $0.5 \mathrm{~mm}$. 
number of aggregate centres formed (this paper; Kahn, 1964; Perekalin, 1977). However, we find that there are three types of round cells: inactive, transiently active (also seen by Shaffer, 1961) and active founder cells. We do not know how these classes are related to each other; possibly they represent stages in the differentiation of founder cells. In addition, we find that light does not affect the number of round cells nor, very strongly, the number of aggregates formed in our enclosed chambers. In our chambers we find that many aggregates do not develop further. In the chambers used by Shaffer (1961), aggregation was abnormal and amoebae did not proceed beyond aggregation. In addition, in Shaffer's experiments, aggregation did not occur in the dark but was triggered by incubation of low density cells in the light. We find founder cells and aggregates formed both in the light and dark under our experimental conditions. Differences between our observations and those of Shaffer may be due to strain differences or differences in experimental parameters. Our amoebae were preincubated in liquid culture until they were aggregation-competent before being spread on a solid surface, whereas in Shaffer's experiments, growth and development were in enclosed chambers. Much more work is necessary to understand the relationship between round cells and active founder cells. However, founder cells should not be thought of as a special predetermined class of cells, even though their numbers seem to be fairly constant between 2 to $4 \mathrm{~h}$ of development when our observations were made. We assume that every cell has a finite probability of differentiating into a founder cell.

$\mathrm{D}$ factor also stimulates the number of aggregate centres formed and very closely mimics the morphological effects of light on aggregation. Round cells are present during development of the agg $A$ mutants even in the absence of $\mathrm{D}$ factor, but active founder cells only arise if $\mathrm{D}$ factor is added. The number of round cells both in mutant and wild-type populations increases slightly in the presence of $D$ factor (data not shown), though we do not know if this is due to an induction of founder cells.

Light also has a fine tuning effect on production of and response to $D$ factor. As shown in this paper, production of $\mathrm{D}$ factor was significantly reduced when wild-type amoebae were allowed to develop in light as opposed to darkness. In contrast, the response of the agg A586 mutant and wild-type amoebae to D factor was much greater in light than in darkness. Normally, D factor was produced during preaggregation and its production decreased later in development. Since aggregation occurred sooner in light than in darkness, it seemed reasonable that less D factor would be produced. Also, as amoebae were more responsive to $\mathrm{D}$ factor in the presence of light, less $\mathrm{D}$ factor would be needed in order for aggregation to begin.

Mato \& Konijn $(1975,1976)$ have shown that ATP advances the time when aggregation begins in $D$. discoideum, possibly by phosphorylation of membrane proteins. Perekalin (1977) has extended these findings to Polysphondylium and has shown that ATP stimulates both the onset of aggregation and the number of aggregate centres formed, also that light and ATP produce the greatest stimulation of aggregation. D factor is not ATP, since ATP over a wide range of concentrations does not stimulate aggregation of the aggA586 mutant (M. H. Hanna, unpublished observation). Most likely, a model for founder cell differentiation should involve ATP, D factor and light. Although founder cells were observed over twenty years ago, no physiological studies of them have been undertaken. Such studies will be made easier by the use of $\mathrm{D}$ factor, light and the agg $A$ mutant.

This project was supported by funds from Grant no. 1 RO1 GM27892-02 awarded by the National Institutes of Health. We would like to acknowledge Ms Debra Neifeld for able technical assistance and Drs J. T. Bonner, E. C. Cox, and H. Roy for critical reading of the manuscript.

\section{REFERENCES}

Beug, H., Katz, F. E. \& Gerisch, G. (1973). Dynamics of antigenic membrane sites relating to cell aggregation in Dictyostelium discoideum. Journal of Cell Biology 56, 647-658.

BONNER, J. T. (1947). Evidence for the formation of cell aggregates by chemotaxis in the development of the slime mold Dictyostelium discoideum. Journal of Experimental Zoology 106, 1-16.
Bonner, J. T., Clarke, W. W. JR, NeEly, C. L., JR \& Slifkin, M. K. (1950). The orientation to light and the extremely sensitive orientation to temperature gradients in the slime mold Dictyostelium discoideum. Journal of Cellular and Comparative Physiology 36, 149-158.

Folch, J., Lees, M. \& Sloane Stanley, G. H. (1957). A simple method for the isolation and purification of 
total lipids from animal tissues. Journal of Biological Chemistry 226, 497-509.

FranCIS, D. W. (1964). Some studies on phototaxis of Dictyostelium. Journal of Cellular and Comparative Physiology 64, 131-138.

GARDNER, J. L. \& HANNA, M. H. (1982). Calcium, cellular adhesion and aggregation competence in the cellular slime mold Polysphondylium violaceum. Experimental Cell Research 137, 169-179.

HADER, D. P. \& PoFf, K. L. (1979a). Light-induced accumulations of Dictyostelium discoideum amoebae. Photochemistry and Photobiology 29, 11571162.

Hader, D. P. \& PofF, K. L. (1979 $b$ ). Inhibition of aggregation by light in the cellular slime mold Dictyostelium discoideum. Archives of Microbiology 123, 281-285.

HanNa, M. H. \& Cox, E. C. (1978). The regulation of cellular slime mold development: a factor causing development of Polysphondylium violaceum aggregation-defective mutants. Developmental Biology 62, 206-214.

KAHN, A. J. (1964). The influence of light on cell aggregation in Polysphondylium pallidum. Biological Bulletin 127, 85-96.

KONIJN, T. M. \& RAPER, K. B. (1961). Cell aggregation in Dictyostelium discoideum. Developmental Biology 3, 725-756.

KONIJN, T. M. \& RAPER, K. B. (1965). The influence of light on the time of cell aggregation in the Dictyosteliaceae. Biological Bulletin 128, 392-400.

KONIJN, T. M. \& RAPER, K. B. (1966). The influence of light on the size of aggregations in Dictyostelium discoideum. Biological Bulletin 131, 446-456.

Mato, J. M. \& Konisn, T. M. (1975). Enhanced cell aggregation in Dictyostelium discoideum by ATP activation of cyclic AMP receptors. Developmental Biology 47, 233-235.
Mato, J. M. \& KoniJn, T. M. (1976). The activation of cell aggregation by phosphorylation in Dictyostelium discoideum. Experimental Cell Research 99, 328-332.

Newell, P. C., Telser, A. \& Sussman, M. (1969). Alternative developmental pathways determined by environmental conditions in the cellular slime mold Dictyostelium discoideum. Journal of Bacteriology 100, 763-768.

Perekalin, D. (1977). The influence of light and different ATP concentrations on cell aggregation in cyclic AMP sensitive and insensitive species of the cellular slime molds. Archives of Microbiology 115, 333-337.

Poff, K. L., Butler, W. L. \& LoOmis, W. F., JR (1973). Light-induced absorbance changes associated with phototaxis in Dictyostelium. Proceedings of the National Academy of Sciences of the United States of America 70, 813-816.

SHAFFER, B. M. (1961). The cells founding aggregation centers in the slime mould Polysphondylium violaceum. Journal of Experimental Biology 38, 833-849.

VOGEL, H. J. \& BONNER, D. M. (1956). Acetylornithinase of Escherichia coli: partial purification and some properties. Journal of Biological Chemistry 218, 97-106.

Warren, A. J., Warren, W. D. \& CoX, E. C. (1975). Genetic complexity of aggregation in the cellular slime mold Polysphondylium violaceum. Proceedings of the National Academy of Sciences of the United States of America 72, 1041-1042.

WARREN, A. J., WARREN, W. D. \& CoX, E. C. (1976). Genetic and morphological study of aggregation in the cellular slime mold Polysphondylium violaceum. Genetics 83, 25-47.

WEBER, A. T. (1970). Drug resistant and morphogenetically aberrant mutants of Dictyostelium discoideum. Ph.D. thesis, University of Wisconsin, Madison, Wisconsin, U.S.A. 